\title{
Assessment of Groundwater Quality in Central India
}

\author{
Shabya Choudhary1, Shobhana Ramteke1, Keshaw Prakash Rajhans1, Pravin Kumar Sahu1, \\ Suryakant Chakradhari1, Khageshwar Singh Patel ${ }^{1}$, Laurent Matini2 \\ ${ }^{1}$ School of Studies in Chemistry/Environmental Science, Pt. Ravishankar Shukla University, Raipur, India \\ ${ }^{2}$ Department of Exact Sciences, E.N.S., Marien Ngouabi University, Brazzaville, Congo \\ Email: "patelks_55@hotmail.com
}

Received 12 November 2015; accepted 8 January 2016; published 11 January 2016

Copyright (C) 2016 by authors and Scientific Research Publishing Inc.

This work is licensed under the Creative Commons Attribution International License (CC BY). http://creativecommons.org/licenses/by/4.0/

cc) (i) Open Access

\section{Abstract}

The groundwater is widely used for irrigation of rice crops. The overuse of groundwater causes depletion of the water quality (i.e. enormous increase in conductivity, hardness and ion and metal contents, etc.) in several regions of the country and world. In this work, the quality of the groundwater in the densestrice cropping area, Saraipali, Chhattisgarh, Central India is discussed. The water is sodic in nature with extremely high electrical conductivity. The mean concentration $(\mathrm{n}=$ 30) of $\mathrm{F}^{-}, \mathrm{Cl}^{-}, \mathrm{NO}_{3}^{-}, \mathrm{SO}_{4}^{2-}, \mathrm{NH}_{4}^{+}, \mathrm{Na}^{+}, \mathrm{K}^{+}, \mathrm{Mg}^{2+}, \mathrm{Ca}^{2+}$ and $\mathrm{Fe}$ in the water was $1.2 \pm 0.2,98 \pm 31,46 \pm$ $15,56 \pm 9,19 \pm 4,206 \pm 25,9.2 \pm 2.3,39 \pm 6,114 \pm 19$ and $1.7 \pm 0.6 \mathrm{mg} / \mathrm{L}$, respectively. The sources of the contaminants are apportioned by using the factor analysis model. The suitability of the groundwater for the drinking and irrigation purposes is assessed.

\section{Keywords}

\section{Groundwater, Indices, Sources}

\section{Introduction}

The urban groundwater has emerged as one of the world's most challenging issues due to large users and contamination with chemicals of geogenic and anthropogenic origins [1]. The quality of available groundwater was degraded enormously by enhancing conductivity, alkalinity, hardness and contaminant levels [2]-[15]. Hence, in this work, the groundwater quality of the rice growing area, Saraipali block, Mahasamund, Chhattisgarh, India was selected for the assessment and rating.

"Corresponding author.

How to cite this paper: Choudhary, S., Ramteke, S., Rajhans, K.P., Sahu, P.K., Chakradhari, S., Patel, K.S. and Matini, L. (2016) Assessment of Groundwater Quality in Central India. Journal of Water Resource and Protection, 8, 12-19. 


\section{Materials and Methods}

\subsection{Study Area}

Saraipali $\left(21.33^{\circ} \mathrm{N} 83.0^{\circ} \mathrm{E}\right)$ is a block in Mahasamund district, Chhattisgarh state, India, including 299 town and villages inclusive of Saraipali town with population of $\approx 0.3$ million. The rice is a main crop of the area with use surplus amount of groundwater to take the multiple crops in a year. The water is hard and become turbid on the storage due to precipitation of the metals i.e. $\mathrm{Mg}$, $\mathrm{Ca}$ and $\mathrm{Fe}$ into oxides and hydroxides. The health problems (i.e. tiredness, diarrhea, stone formation in kidney and spleen, etc.) in the residence of the studied area due to intake of the groundwater were marked. Therefore, in the present work, the water quality assessment of Saraipali area was chosen.

\subsection{Sample Collection}

The groundwater samples were collected from 30 locations of the town and nearby villages, Figure 1 . The water was collected in the post monsoon period, January, 2014 in a 1-L cleaned polyethylene bottle by using established methodology [16]. The bottle was ringed thrice with the sampling water prior to collection and filled up to the mouth with the water. The physical parameters i.e. $\mathrm{pH}$, temperature (T), electrical conductivity (EC), reduction potential (RP) and dissolved oxygen (DO) were measured at the spot.

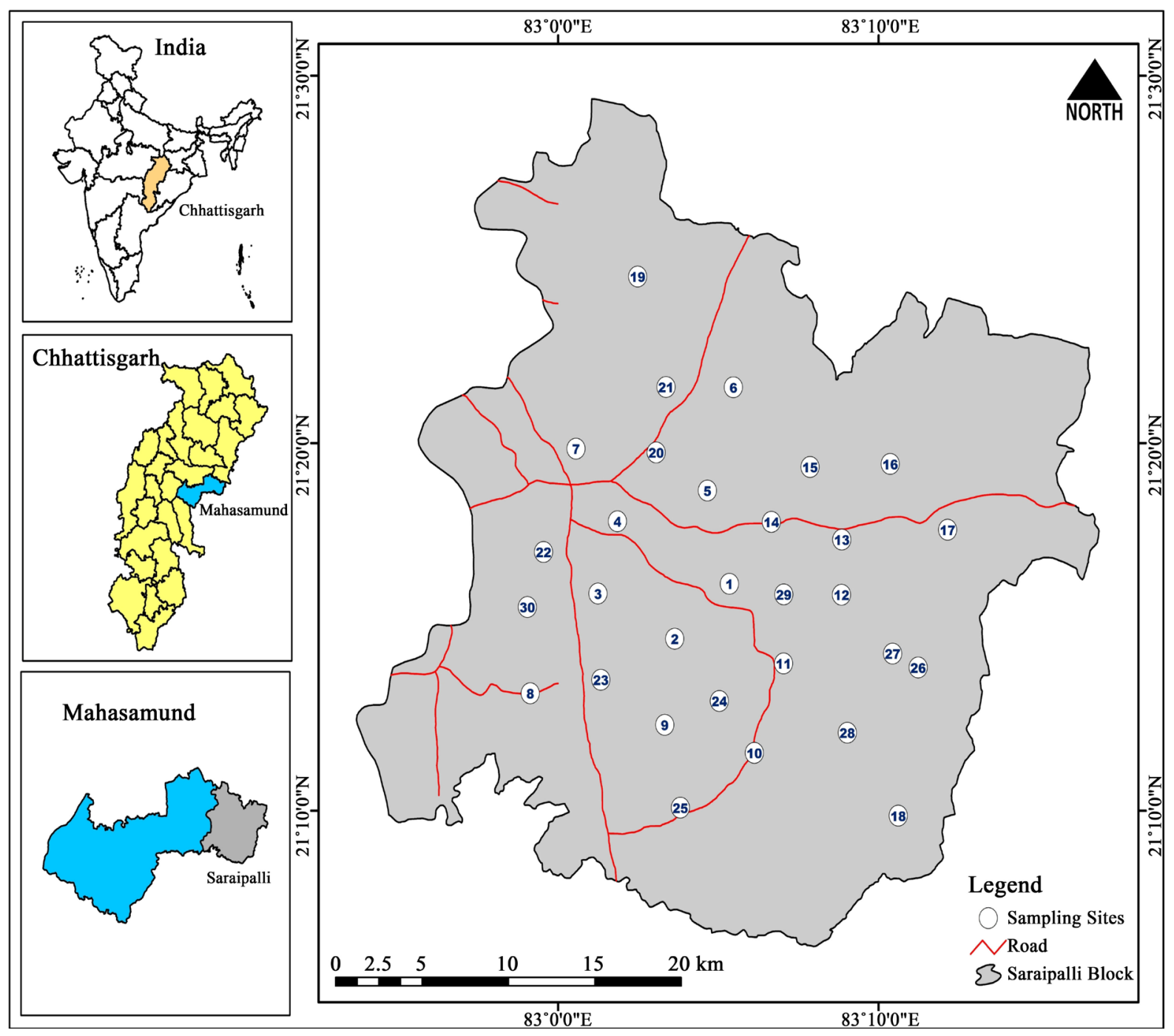

Figure 1. Representation of sampling locations in Chhattisgarh, India. 


\subsection{Analysis}

The Hanna water analyzer kits was used for the measurement of the physical parameters. The total dissolved solid (TDS) value was determined by evaporation method by prior filtering the water through glass fiber with subsequent drying at the constant weight [16]. The total hardness (TH) and total alkalinity (TA) values were analyzed by titration methods [17]. The Metrohm ion meter-781 was used for monitoring of $\mathrm{F}^{-}$by using the buffer in a 1:1 volume ratio. The Dionex ion chromatography-1100 was used for the quantification of the ions. Multivariate statistical model i.e. factor analysis (FA) was used for the source apportionment of ions and metals [18]. The statistical software STATISTICA 7.1 was employed for the multivariate statistical calculations.

The various water quality indices i.e. sodium adsorption ratio (SAR), sodium hazard (SH) and water quality index (WQI) were used for rating of the water quality. The weighed arithmetic method was employed for computation of the WQI of the groundwater by using four parameters i.e. pH, DO, EC and TDS [19] [20]. The following equations were used for calculation of the indices.

$$
\begin{aligned}
& \text { SAR }=\left[\mathrm{Na}^{+}\right] / \sqrt{\left\{\left(\left[\mathrm{Ca}^{2+}\right]+\left[\mathrm{Mg}^{2+}\right]\right) / 2\right\}} \\
& \mathrm{SH}=(\{[\mathrm{Na}]+[\mathrm{K}]\} /\{[\mathrm{Na}]+[\mathrm{K}]+[\mathrm{Mg}]+[\mathrm{Ca}]\}) \times 100
\end{aligned}
$$

The equivalent concentrations of cations were used.

$$
\begin{aligned}
& \mathrm{WQI}=\sum q_{n} W_{n} / \sum W_{n} \\
& q_{n}=100\left(V_{n}-V_{\text {io }}\right) /\left(S_{n}-V_{\text {io }}\right)
\end{aligned}
$$

$q_{n}=$ Quality rating of the $n$th water quality parameter.

$V_{n}=$ Estimated value of the $n$th parameter of a given water.

$S_{n}=$ Standard permissible value of the $n$th parameter.

$V_{i o}=$ Ideal value of the $n$th parameter of pure water (i.e. 0 for all other parameters except $\mathrm{pH}$ and dissolved oxygen (7.0 and $14.6 \mathrm{mg} / \mathrm{L}$, respectively).

$\mathrm{W}_{\mathrm{n}}=$ Unit weight for the $n$th parameter.

\section{Results and Discussion}

\subsection{Geology}

Chhattisgarh basin is characterized by rocks belonging to Proterozoic aged sandstone, limestone, and dolomite, conglomerate, etc. Siliciclastic-carbonates are deposited in muddy shelf and platformer environment, indicative of more stable tectonic condition. Its deposition is controlled by several cycles of transgressions and regressions. The Proterozoic grouprocks are found to spread over the studied area. The gypsum minerals are found to be more intense than calcareous minerals, containing both toxic and precious elements at traces.

The physical characteristics of 30 tube well of Saraipali area is summarized in Table 1. The depth of tube well $(n=30)$ is moderate, ranging from $24-63 \mathrm{~m}$ with mean value of $32 \pm 2 \mathrm{~m}$. The ionic contamination of the water was found to be related with the depth profile of the tube wells and increased as the depth profile was increased $(r=0.59)$. The age of tube wells was ranged from 7 - 25 Yr with mean value of $17 \pm 2$ Yr. The water quality was also found to be influenced by the age of tube wells.

\subsection{Physical Characteristics of Water}

The chemical characteristics of the groundwater are presented in Table 2. The T, DO, RP and $\mathrm{pH}$ value of water $\left(\mathrm{n}=30\right.$ ) was ranged from $19^{\circ} \mathrm{C}-22^{\circ} \mathrm{C}, 4.8-5.4 \mathrm{mg} / \mathrm{L}, 117-238 \mathrm{mV}$ and $6.2-8.3$ with mean value of $20.9^{\circ} \mathrm{C} \pm$ $0.3^{\circ} \mathrm{C}, 5.1 \pm 0.1 \mathrm{mg} / \mathrm{L}, 187 \pm 9 \mathrm{mV}$ and $6.88 \pm 0.13$, respectively. In some locations, the water was found to be slightly acidic due to higher $\mathrm{Cl}^{-}$and $\mathrm{NO}_{3}^{-}$contents. The EC, TDS, TA and TH value of water was ranged from 785 - $4589 \mu \mathrm{S} / \mathrm{cm}, 651-2836 \mathrm{mg} / \mathrm{L}, 159-610 \mathrm{mg} / \mathrm{L}$ and $186-864 \mathrm{mg} / \mathrm{L}$ with mean value of $1946 \pm 363 \mu \mathrm{S} / \mathrm{cm}$, $1411 \pm 221 \mathrm{mg} / \mathrm{L}, 352 \pm 45 \mathrm{mg} / \mathrm{L}$ and $355 \pm 58 \mathrm{mg} / \mathrm{L}$, respectively. The EC value was mainly contributed by the ions i.e. $\mathrm{Na}^{+}, \mathrm{K}^{+}, \mathrm{Cl}^{-}, \mathrm{NO}_{3}^{-}$and $\mathrm{SO}_{4}^{2-} \quad(\mathrm{r}=0.93)$. 
Table 1. Geophysical characteristics of tube well and groundwater during January, 2014.

\begin{tabular}{|c|c|c|c|c|c|c|c|c|}
\hline S. No. & Location & Age, Yr & Depth, m & $\mathrm{T},{ }^{\circ} \mathrm{C}$ & $\mathrm{pH}$ & $\mathrm{EC}, \mu \mathrm{S} / \mathrm{cm}$ & $\mathrm{RP}, \mathrm{mV}$ & $\mathrm{DO}, \mathrm{mg} / \mathrm{L}$ \\
\hline 1 & Joganipalidipa & 22 & 30 & 22 & 7.1 & 1169 & 200 & 5.2 \\
\hline 2 & Joganipali & 10 & 30 & 22 & 6.2 & 1776 & 187 & 5.3 \\
\hline 3 & Kejuan & 18 & 33 & 21 & 6.9 & 966 & 170 & 5.2 \\
\hline 4 & Harratar & 13 & 27 & 21 & 7.2 & 1433 & 212 & 5.0 \\
\hline 5 & Kutela & 15 & 24 & 21 & 7.1 & 1099 & 139 & 5.4 \\
\hline 6 & Bastisaraipali & 19 & 27 & 22 & 7.0 & 2097 & 165 & 5.0 \\
\hline 7 & Madhopali & 17 & 27 & 22 & 7.0 & 1190 & 238 & 5.1 \\
\hline 8 & Parsada & 16 & 24 & 22 & 7.2 & 1127 & 186 & 5.3 \\
\hline 9 & Telidipa & 12 & 27 & 21 & 6.8 & 888 & 180 & 5.0 \\
\hline 10 & Lukapara & 7 & 63 & 21 & 6.8 & 3770 & 187 & 4.8 \\
\hline 11 & Lakhanpali & 21 & 33 & 20 & 6.8 & 1209 & 218 & 5.3 \\
\hline 12 & Barihapali & 10 & 48 & 20 & 6.8 & 2545 & 191 & 4.9 \\
\hline 13 & Mokhaputka & 25 & 33 & 21 & 6.6 & 2467 & 181 & 4.9 \\
\hline 14 & Kumhardipa & 17 & 36 & 22 & 6.5 & 1375 & 214 & 5.1 \\
\hline 15 & Saraipali & 20 & 30 & 22 & 6.7 & 1100 & 183 & 5.0 \\
\hline 16 & Paterapali & 15 & 33 & 22 & 6.9 & 4589 & 161 & 5.3 \\
\hline 17 & Balsi & 25 & 33 & 22 & 6.5 & 1928 & 172 & 5.1 \\
\hline 18 & Kendudhar & 24 & 30 & 21 & 7.2 & 1910 & 219 & 5.1 \\
\hline 19 & Bichhiyan & 22 & 33 & 21 & 7.0 & 4082 & 205 & 5.2 \\
\hline 20 & Sagarpali & 18 & 39 & 20 & 6.8 & 3666 & 194 & 5.1 \\
\hline 21 & Amarkot & 22 & 24 & 21 & 6.6 & 1080 & 188 & 5.0 \\
\hline 22 & Mohda & 20 & 27 & 20 & 6.3 & 1888 & 163 & 5.4 \\
\hline 23 & Navrangpur & 18 & 33 & 20 & 7.1 & 1251 & 172 & 5.3 \\
\hline 24 & Patsendri & 16 & 36 & 20 & 7.1 & 2730 & 194 & 5.2 \\
\hline 25 & Bonda & 17 & 36 & 20 & 7.0 & 3094 & 201 & 5.1 \\
\hline 26 & Girsa & 15 & 33 & 19 & 8.3 & 2045 & 117 & 5.1 \\
\hline 27 & Jambahlin & 20 & 27 & 20 & 6.9 & 1806 & 213 & 5.1 \\
\hline 28 & Baitari & 15 & 30 & 21 & 6.8 & 1340 & 226 & 5.4 \\
\hline 29 & Chattigirhola & 16 & 33 & 21 & 7.0 & 785 & 157 & 5.2 \\
\hline 30 & Echchhapur & 18 & 30 & 20 & 7.1 & 1968 & 170 & 5.2 \\
\hline
\end{tabular}

Table 2. Chemical characteristics of groundwater during January, 2014, mg/L.

\begin{tabular}{cccccccccccccc}
\hline S. No. & TDS & TA & TH & $\mathrm{F}$ & $\mathrm{Cl}^{-}$ & $\mathrm{NO}_{3}^{-}$ & $\mathrm{SO}_{4}^{2-}$ & $\mathrm{NH}_{4}^{+}$ & $\mathrm{Na}^{+}$ & $\mathrm{K}^{+}$ & $\mathrm{Ca}^{2+}$ & $\mathrm{Mg}^{2+}$ & $\mathrm{Fe}^{2}$ \\
\hline 1 & 748 & 353 & 210 & 0.8 & 27 & 22 & 27 & 13 & 156 & 9.5 & 57 & 34 & 2.4 \\
2 & 1183 & 298 & 318 & 0.9 & 92 & 29 & 44 & 15 & 246 & 5.5 & 99 & 39 & 3.8 \\
3 & 857 & 286 & 243 & 0.6 & 18 & 21 & 69 & 12 & 118 & 6.0 & 75 & 30 & 2.4 \\
4 & 896 & 420 & 306 & 1.2 & 36 & 28 & 31 & 14 & 163 & 6.5 & 101 & 31 & 0.5 \\
5 & 651 & 286 & 207 & 0.8 & 18 & 18 & 38 & 11 & 125 & 4.0 & 68 & 22 & 1.1 \\
6 & 1310 & 311 & 330 & 1.3 & 129 & 18 & 53 & 17 & 218 & 17.0 & 101 & 42 & 0.7 \\
7 & 1028 & 335 & 246 & 0.9 & 27 & 14 & 42 & 31 & 146 & 5.5 & 75 & 31 & 1.1 \\
8 & 1071 & 237 & 246 & 1.0 & 42 & 104 & 34 & 7 & 118 & 6.5 & 75 & 31 & 0.4 \\
9 & 978 & 347 & 408 & 1.6 & 23 & 29 & 39 & 9 & 102 & 8.5 & 130 & 47 & 2.1 \\
10 & 2588 & 585 & 693 & 1.8 & 190 & 120 & 40 & 31 & 311 & 4.0 & 226 & 74 & 0.4 \\
\hline
\end{tabular}




\begin{tabular}{|c|c|c|c|c|c|c|c|c|c|c|c|c|c|}
\hline \multicolumn{14}{|c|}{ Continued } \\
\hline 11 & 906 & 280 & 258 & 0.8 & 36 & 32 & 69 & 7 & 163 & 4.5 & 86 & 26 & 0.8 \\
\hline 12 & 1731 & 384 & 501 & 1.9 & 125 & 23 & 57 & 26 & 254 & 9.5 & 164 & 53 & 0.9 \\
\hline 13 & 1868 & 317 & 471 & 1.8 & 134 & 67 & 79 & 19 & 233 & 3.0 & 153 & 51 & 1.5 \\
\hline 14 & 1554 & 170 & 186 & 0.8 & 65 & 163 & 38 & 23 & 175 & 7.0 & 62 & 18 & 1.2 \\
\hline 15 & 805 & 213 & 222 & 0.7 & 51 & 15 & 36 & 11 & 156 & 14.0 & 73 & 23 & 2.7 \\
\hline 16 & 2836 & 464 & 864 & 2.2 & 374 & 42 & 47 & 12 & 351 & 5.5 & 286 & 88 & 0.6 \\
\hline 17 & 1646 & 183 & 471 & 1.9 & 166 & 34 & 46 & 13 & 251 & 11.0 & 156 & 48 & 1.4 \\
\hline 18 & 1106 & 573 & 276 & 0.8 & 42 & 22 & 79 & 15 & 260 & 36.0 & 83 & 36 & 0.6 \\
\hline 19 & 2626 & 543 & 513 & 1.7 & 254 & 120 & 68 & 29 & 311 & 5.0 & 151 & 72 & 1.9 \\
\hline 20 & 2207 & 610 & 438 & 1.6 & 231 & 68 & 42 & 33 & 317 & 13.5 & 138 & 52 & 0.4 \\
\hline 21 & 1212 & 244 & 348 & 1.2 & 36 & 22 & 88 & 17 & 155 & 8.5 & 117 & 34 & 7 \\
\hline 22 & 1960 & 159 & 327 & 1.1 & 120 & 153 & 100 & 13 & 248 & 5.5 & 112 & 30 & 6.9 \\
\hline 23 & 963 & 268 & 222 & 1.0 & 47 & 25 & 85 & 12 & 131 & 8.0 & 70 & 26 & 2.1 \\
\hline 24 & 1854 & 360 & 543 & 1.8 & 161 & 32 & 39 & 28 & 282 & 13.0 & 179 & 56 & 1.1 \\
\hline 25 & 1948 & 329 & 552 & 1.9 & 231 & 28 & 35 & 19 & 257 & 20.0 & 182 & 57 & 1.2 \\
\hline 26 & 2022 & 372 & 231 & 1.1 & 116 & 21 & 140 & 57 & 226 & 6.0 & 75 & 25 & 0.3 \\
\hline 27 & 1097 & 433 & 354 & 1.2 & 47 & 21 & 43 & 18 & 179 & 5.0 & 117 & 36 & 1.1 \\
\hline 28 & 945 & 402 & 219 & 0.8 & 34 & 26 & 61 & 18 & 152 & 12.0 & 70 & 25 & 3.1 \\
\hline 29 & 792 & 244 & 216 & 0.9 & 35 & 31 & 46 & 12 & 122 & 8.0 & 73 & 21 & 1.5 \\
\hline 30 & 956 & 549 & 228 & 0.7 & 47 & 31 & 60 & 16 & 260 & 7.5 & 73 & 26 & 0.9 \\
\hline
\end{tabular}

\subsection{Chemical Characteristics of Water}

The concentration of $\mathrm{F}^{-}, \mathrm{Cl}^{-}, \mathrm{NO}_{3}^{-}, \mathrm{SO}_{4}^{2-}, \mathrm{NH}_{4}^{+}, \mathrm{Na}^{+}, \mathrm{K}^{+}, \mathrm{Mg}^{2+}, \mathrm{Ca}^{2+}$ and Fe was ranged from 0.6 - 2.2, 18 374, 14 - 163, 27 - 140, 7.0 - 57, 102 - 351, 3.0 - 36, 18 - 88, 57 - 286 and 0.3 - 7.0 mg/L with mean value of 1.2 \pm 0.2, $98 \pm 31,46 \pm 15,56 \pm 9,19 \pm 4,206 \pm 25,9.2 \pm 2.3,39 \pm 6,114 \pm 19$ and $1.7 \pm 0.6 \mathrm{mg} / \mathrm{L}$, respectively. Among them, $\mathrm{Na}^{+}$showed the highest content followed by $\mathrm{Ca}^{2+}$ and $\mathrm{Cl}^{-}$. The highest ionic content was marked at locations lying close to at the highway junctions and water reservoirs due to their increased mineralization in the groundwater, Figure 2.

\subsection{Source}

The correlation coefficient matrix of the water variables are shown in Table 3. Among them, ions i.e. $\mathrm{F}^{-}, \mathrm{Cl}^{-}$, $\mathrm{Na}^{+}, \mathrm{Mg}^{2+}$ and $\mathrm{Ca}^{2+}$ were found to be well correlated, showing origin from the common sources. The molar ratio of $\left[\mathrm{Na}^{+}\right] /\left[\mathrm{Cl}^{-}\right]$was ranged from $1.5-11$ with mean value of $5 \pm 1$, indicating both geogenic and anthropogenic origins of $\mathrm{Na}$ in the water.

The FA model showed the extraction of six factors with account for $84.04 \%$ of total variance, Table 4 . Factor- 1 accounts for $39.27 \%$ of the total variance with strong positive loadings of $\mathrm{TH}, \mathrm{Ca}^{2+}, \mathrm{Mg}^{2+}, \mathrm{F}^{-}, \mathrm{Cl}^{-}, \mathrm{EC}$ and TDS; related to hardness depending on the weathering of fluoride bearing materials such as $\mathrm{CaF}_{2}$. Factor- 2 explains $14.79 \%$ of the total variance with high positive loading of $\mathrm{SO}_{4}^{2-}$, correlated to evaporation of the water. Factor-3 explains $9.06 \%$ of the total variance with high positive loading of alkalinity in opposition to Fe. Factor4 accounts for $8.32 \%$ of the total variance with a negative loading of DO. Factor 5 explains $6.87 \%$ of the total variance with a negative loading of the variable Age of the tube wells. Factor- 6 accounts for $5.74 \%$ of the total variance with a high positive loading of $\mathrm{NO}_{3}{ }^{-}$, indicating agricultural impacts in the water.

\subsection{Water Quality}

The value of TA, TH, Mg, Ca and Fe content was found to be higher than recommended value of 120, 200, 30, 75 and $0.30 \mathrm{mg} / \mathrm{L}$, respectively [19] [20]. The value of SAR, SH and WQI was ranged from $1.8 \%-28 \%, 19 \%$ $84 \%$ and $86 \%-713 \%$ with mean value of $6.6 \% \pm 1.7 \%, 50 \% \pm 5 \%$ and $275 \% \pm 60 \%$, respectively. The 


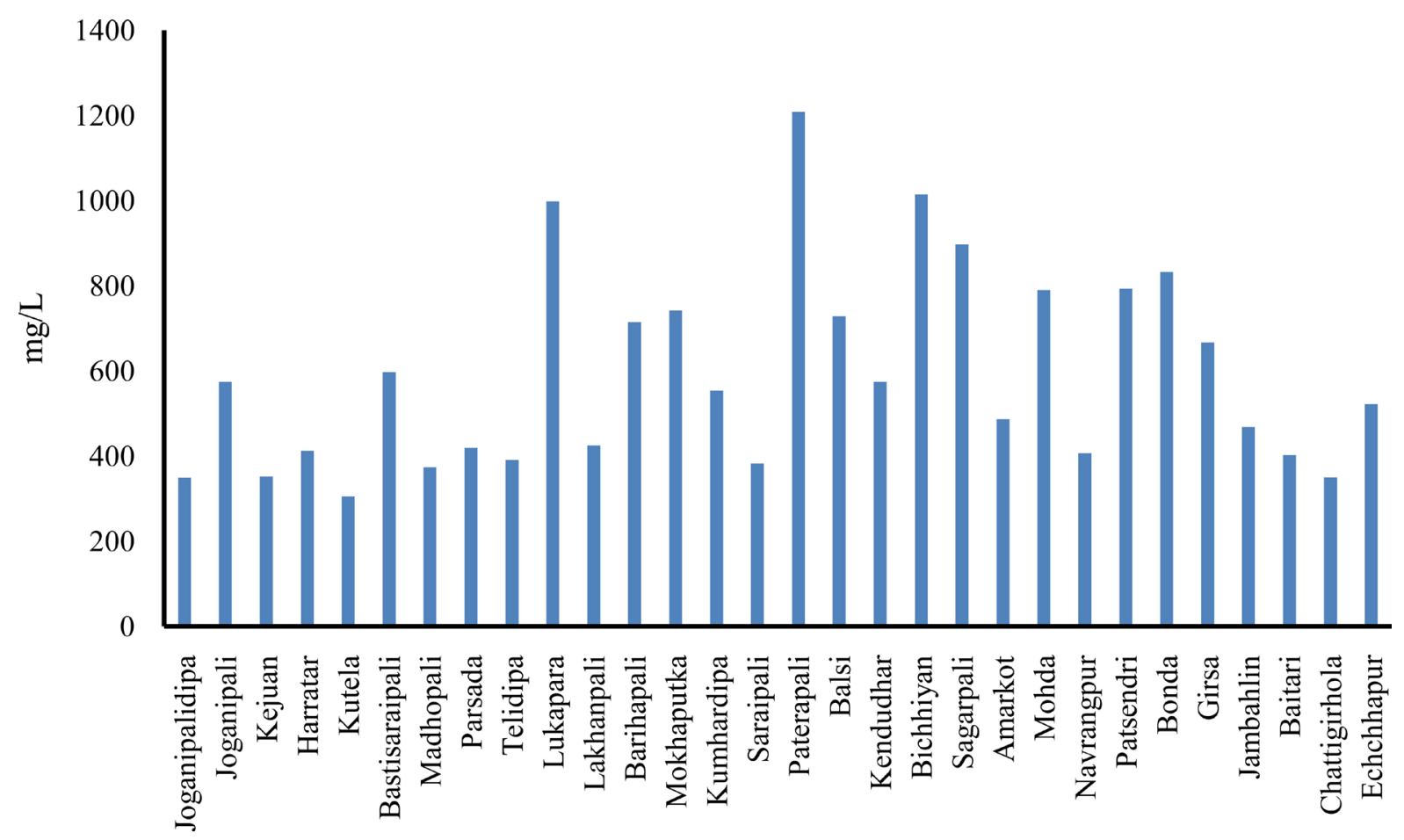

Location

Figure 2. Spatial variations in sum of total concentration of the ions.

Table 3. Correlation coefficient matrix of elements in water.

\begin{tabular}{|c|c|c|c|c|c|c|c|c|c|c|}
\hline & $\mathrm{F}^{-}$ & $\mathrm{Cl}^{-}$ & $\mathrm{NO}_{3}^{-}$ & $\mathrm{SO}_{4}^{2-}$ & $\mathrm{NH}_{4}^{+}$ & $\mathrm{Na}^{+}$ & $\mathrm{K}^{+}$ & $\mathrm{Ca}^{2+}$ & $\mathrm{Mg}^{2+}$ & $\mathrm{Fe}$ \\
\hline $\mathrm{F}^{-}$ & 1 & & & & & & & & & \\
\hline $\mathrm{Cl}^{-}$ & 0.81 & 1 & & & & & & & & \\
\hline $\mathrm{NO}_{3}^{-}$ & 0.15 & 0.29 & 1 & & & & & & & \\
\hline $\mathrm{SO}_{4}^{2-}$ & -0.11 & -0.01 & 0.03 & 1 & & & & & & \\
\hline $\mathrm{NH}_{4}^{+}$ & 0.24 & 0.32 & 0.11 & 0.40 & 1 & & & & & \\
\hline $\mathrm{Na}^{+}$ & 0.65 & 0.86 & 0.29 & 0.09 & 0.42 & 1 & & & & \\
\hline $\mathrm{K}^{+}$ & -0.02 & 0.02 & -0.26 & -0.02 & -0.05 & 0.18 & 1 & & & \\
\hline $\mathrm{Ca}^{2+}$ & 0.91 & 0.85 & 0.17 & -0.14 & 0.15 & 0.73 & -0.05 & 1 & & \\
\hline $\mathrm{Mg}^{2+}$ & 0.88 & 0.86 & 0.18 & -0.17 & 0.19 & 0.75 & 0.01 & 0.93 & 1 & \\
\hline $\mathrm{Fe}$ & -0.20 & -0.20 & 0.13 & 0.31 & -0.25 & -0.18 & -0.12 & -0.15 & -0.21 & 1 \\
\hline
\end{tabular}

Table 4. Eigenvalues and factor loadings of groundwater.

\begin{tabular}{ccccccc}
\hline Variable & Factor-1 & Factor-2 & Factor-3 & Factor-4 & Factor-5 & Factor-6 \\
\hline Age & -0.10 & 0.02 & -0.18 & -0.20 & $-\mathbf{0 . 8 3}$ & 0.04 \\
Depth & 0.41 & 0.06 & 0.19 & 0.57 & 0.32 & 0.32 \\
T & -0.06 & -0.67 & -0.20 & -0.01 & -0.11 & 0.09 \\
pH & -0.09 & 0.55 & 0.64 & -0.12 & 0.14 & -0.30 \\
EC & $\mathbf{0 . 8 8}$ & 0.14 & 0.31 & 0.02 & -0.03 & 0.25 \\
RP & -0.15 & -0.59 & 0.33 & 0.22 & -0.35 & 0.30 \\
DO & -0.08 & 0.03 & 0.09 & $-\mathbf{0 . 9 0}$ & 0.07 & 0.10 \\
TDS & $\mathbf{0 . 8 5}$ & 0.30 & 0.10 & 0.07 & 0.02 & 0.40 \\
\hline
\end{tabular}




\begin{tabular}{ccccccc} 
Continued & & & & & & \\
\hline $\mathrm{TA}$ & 0.43 & 0.10 & $\mathbf{0 . 7 6}$ & 0.04 & -0.05 & 0.05 \\
$\mathrm{TH}$ & $\mathbf{0 . 9 7}$ & -0.02 & 0.09 & 0.07 & 0.14 & 0.00 \\
$\mathrm{~F}^{-}$ & $\mathbf{0 . 9 1}$ & 0.08 & 0.04 & 0.15 & 0.11 & -0.07 \\
$\mathrm{Cl}^{-}$ & $\mathbf{0 . 9 1}$ & 0.10 & 0.07 & -0.02 & -0.05 & 0.19 \\
$\mathrm{NO}_{3}^{-}$ & 0.21 & -0.02 & -0.17 & -0.08 & 0.10 & $\mathbf{0 . 8 5}$ \\
$\mathrm{SO}_{4}^{2-}$ & -0.03 & $\mathbf{0 . 8 7}$ & -0.15 & -0.12 & -0.21 & 0.08 \\
$\mathrm{NH}_{4}^{+}$ & 0.18 & 0.67 & 0.44 & 0.32 & 0.06 & 0.33 \\
$\mathrm{Na}^{+}$ & 0.29 & 0.66 & 0.40 & 0.31 & 0.00 & 0.36 \\
$\mathrm{~K}^{+}$ & -0.08 & -0.10 & -0.04 & 0.40 & -0.69 & -0.28 \\
$\mathrm{Ca}^{2+}$ & $\mathbf{0 . 9 6}$ & -0.01 & 0.06 & 0.07 & 0.16 & -0.01 \\
$\mathrm{Mg}^{2+}$ & $\mathbf{0 . 9 5}$ & -0.05 & 0.19 & 0.06 & 0.06 & 0.04 \\
Fe & -0.24 & -0.01 & $-\mathbf{0 . 7 6}$ & 0.06 & -0.33 & 0.15 \\
Eigenvalue & 7.85 & 2.96 & 1.81 & 1.66 & 1.37 & 1.15 \\
\% Total variance & 39.27 & 14.79 & 9.06 & 8.32 & 6.87 & 5.74 \\
Cumulative \% & 39.27 & 54.05 & 63.11 & 71.43 & 78.30 & 84.04 \\
\hline
\end{tabular}

classification of groundwater was grouped on the basis of SH values, excellent $(<20 \%)$, good $(20 \%-40 \%)$, permissible $(40 \%-60 \%)$, doubtful $(60 \%-80 \%)$ and unsuitable $(>80 \%)$. It means the water of the studied area was found to be sodic and hard in nature, being unsuitable for the drinking purposes. They could be used for the irrigation purposes but prolonged excessive extraction of the water may cause adverse impacts in rice yields in near future.

\section{Conclusion}

The groundwater of Saraipali area is deteriorated rapidly due to its excessive extraction for the irrigation purposes. The water is sodic and hard in nature. The values of EC, TH, TA, Na, Mg, Ca and Fe were observed to be above reported permissible limits. The water is seemed to be unsuitable for the drinking purposes due to high mineralization of the bed-rock elements in the aquifer. The water could be used for the irrigation of the new varieties rice crops required less water with lower ripping life.

\section{Acknowledgements}

We are thankful to the Pt. Ravishankar Shukla University, Raipur for awarding scholarship to one of the author i.e. SC.

\section{References}

[1] Kulkarni, H., Shah, M. and Vijay Shankar, P.S. (2015) Shaping the Contours of Groundwater Governance in India. Journal of Hydrology: Regional Studies, 4, 172-192. http://dx.doi.org/10.1016/j.ejrh.2014.11.004

[2] Machiwal, D. and Jha, M.K. (2015) Identifying Sources of Groundwater Contamination in a Hard-Rock Aquifer System Using Multivariate Statistical Analyses and GIS-Based Geostatistical Modeling Techniques. Journal of Hydrology: Regional Studies, 4, 80-110. http://dx.doi.org/10.1016/j.ejrh.2014.11.005

[3] Basavarajappa, H.T. and Manjunatha, M.C. (2015) Groundwater Quality Analysis in Precambrian Rocks of Chitradurga District, Karnataka, India Using Geo-Informatics Technique. Aquatic Procedia, 4, 1354-1365. http://dx.doi.org/10.1016/j.aqpro.2015.02.176

[4] Verma, S., Mukherjee, A., Choudhury, R. and Mahanta, C. (2015) Brahmaputra River Basin Groundwater: Solute Distribution, Chemical Evolution and Arsenic Occurrences in Different Geomorphic Settings. Journal of Hydrology: Regional Studies, 4, 131-153. http://dx.doi.org/10.1016/j.ejrh.2015.03.001

[5] Hallett, B.M., Dharmagunawardhane, H.A., Atal, S., Valsami-Jones, E., Ahmed, S. and Burgess, W.G. (2015) Mineralogical Sources of Groundwater Fluoride in Archaen Bedrock/Regolith Aquifers: Mass Balances from Southern India and North-Central Sri Lanka. Journal of Hydrology: Regional Studies, 4, 111-130. 
[6] Banerjee, A. (2015) Groundwater Fluoride Contamination: A Reappraisal. Geoscience Frontiers, 6, 277-284. http://dx.doi.org/10.1016/j.gsf.2014.03.003

[7] Rosin, K.G., Kaur, R., Singh, S.D., Singh, P. and Dubey, D.S. (2013) Groundwater Vulnerability to Contaminated Irrigation Waters-A Case of Peri-Urban Agricultural Lands around an Industrial District of Haryana, India. Procedia Environmental Sciences, 18, 200-210. http://dx.doi.org/10.1016/j.proenv.2013.04.026

[8] Venkateswaran, S. and Deepa, S. (2015) Assessment of Groundwater Quality Using GIS Techniques in Vaniyar Watershed, Ponnaiyar River, Tamil Nadu. Aquatic Procedia, 4, 1283-1290. http://dx.doi.org/10.1016/j.aqpro.2015.02.167

[9] Adnan, S. and Iqbal, J. (2014) Spatial Analysis of the Groundwater Quality in the Peshawar District, Pakistan. Procedia Engineering, 70, 14-22. http://dx.doi.org/10.1016/j.proeng.2014.02.003

[10] Banerjee, S., Das, B., Umlong, I.M., Devi, R.R., Kalita, H., Saikia, L.B., Borah, K., Raul, P.K. and Singh, L. (2011) Heavy Metal Contaminants of Undergroundwater in Indo Bangla Border Districts of Tripura, India. International Journal of ChemTech Research, 3, 516-522. http://sphinxsai.com/Vol.3No.1/chem jan-mar11/pdf/CT=80(516-522)\%20JM11.pdf

[11] Kumar, A., Narang, S., Mehra, R. and Singh, S. (2015) Assessment of Radon Concentration and Heavy Metal Contamination in Groundwater Samples from Some Areas of Fazilka District, Punjab, India. Indoor and Built Environment.

[12] Borah, J. (2011) Monitoring Fluoride Concentration and Some Other Physico-Chemical Properties of Groundwater of Tinsukia District, Assam, India. International Journal of ChemTech Research, 3, 1339-1342.

[13] Singaraja, C., Chidambaram, S., Anandhan, P., Prasanna, M.V., Thivya, C., Thilagavathi, R. and Sarathidasan, J. (2014) Geochemical Evaluation of Fluoride Contamination of Groundwater in the Thoothukudi District of Tamilnadu, India. Applied Water Science, 4, 241-250. http://dx.doi.org/10.1007/s13201-014-0157-y

[14] Singaraja, C., Chidambaram, S., Anandhan, P., Prasanna, M.V., Thivya, C. and Thilagavathi, R. (2013) A Study on the Status of Fluoride Ion in Groundwater of Coastal Hard Rock Aquifers of South India. Arabian Journal of Geosciences, 6, 4167-4177. http://dx.doi.org/10.1007/s12517-012-0675-6

[15] Ghosh, S., Chakraborty, S., Roy, B., Banerjee, P. and Bagchi, A. (2010) Assessment of Health Risks Associated with Fluoride-Contaminated Groundwater in Birbhum District of West Bengal, India. Journal of Environmental Protection Science, 4, 13-21. http://aes.asia.edu.tw/Issues/JEPS2010/GhoshS2010.pdf

[16] APHA (2005) Standard Methods for the Examination of Water and Wastewater. 21st Edition, AWWA, WEF and APHA, Washington DC.

[17] Nollet, L.M.L. and De Gelder, L.S.P. (2007) Handbook of Water Analysis, 2nd Edition, CRC Press, Boca Raton. https://www.crcpress.com/Handbook-of-Water-Analysis-Second-Edition/Nollet-De-Gelder/9780849370335

[18] Shrestha, S. and Kazama, F. (2007) Assessment of Surface Water Quality Using Multivariate Statistical Techniques: A Case Study of the Fuji River Basin, Japan. Environmental Modelling and Software, 22, 464-475. http://dx.doi.org/10.1016/j.envsoft.2006.02.001

[19] BIS (2003) Indian Standard Drinking Water Specifications (IS 10500:1991), Ed. 2.2 (2003-2009), Bureau of Indian Standard, New Delhi. http://www.indiawaterportal.org/sites/indiawaterportal.org/files/drinking_water_standards_is_10500_1991_bis.pdf

[20] WHO (2011) Guidelines for Drinking Water Quality. 4th Edition, World Health Organization, Geneva. http://apps.who.int/iris/bitstream/10665/44584/1/9789241548151_eng.pdf 